University of Nebraska - Lincoln

DigitalCommons@University of Nebraska - Lincoln

Diet analysis reveals pre-historic meals among the Loma San Gabriel at La Cueva de Los Muertos Chiquitos, Rio Zape, Mexico (600-800 CE)

Elisa Pucu

Julia Russ

Karl Reinhard

Follow this and additional works at: https://digitalcommons.unl.edu/natresreinhard

Part of the Archaeological Anthropology Commons, Ecology and Evolutionary Biology Commons, Environmental Public Health Commons, Other Public Health Commons, and the Parasitology Commons

This Article is brought to you for free and open access by the Natural Resources, School of at DigitalCommons@University of Nebraska - Lincoln. It has been accepted for inclusion in Karl Reinhard Papers/ Publications by an authorized administrator of DigitalCommons@University of Nebraska - Lincoln. 


\title{
Diet analysis reveals pre-historic meals among the Loma San Gabriel at La Cueva de Los Muertos Chiquitos, Rio Zape, Mexico (60o-80o CE)
}

\author{
Elisa Pucu, ${ }^{1,2}$ Julia Russ, ${ }^{3}$ and Karl Reinhard ${ }^{1}$ \\ 1 Hardin Hall, School of Natural Resources, University of Nebraska-Lincoln, \\ Lincoln, NE, USA \\ 2 Laboratório de Biologia Molecular de Parasitos e Paleoparasitologia, Instituto \\ Biomédico, Universidade Federal Fluminense, Niterói, Rio de Janeiro, Brazil \\ 3 Morrison Microscopy Core Research Facility, Center for Biotechnology, \\ University of Nebraska-Lincoln, Lincoln, NE, USA
}

Correspondence: Elisa Pucu, elisapucu@id.uff.br

\begin{abstract}
Coprolites have been a source of study for archeologists due to several reasons: they not only provide information on the life and nutritional habits of ancient individuals but also on their health. In this paper, we processed 10 coprolites collected at La Cueva de Los Muertos Chiquitos (6oo-80o CE), Rio Zape, Mexico, with acetolysis solution for pollen analysis. The number of pollen grains/gram of each coprolite sample was quantified along with the macroscopic remains of these samples. The main food item ingested by the population was maize, followed by Agave. Squash blossoms were also part of their food source determined by the presence of pollen grains. In macro remains, we identified rodent bones,
\end{abstract}

Published in Archaeological and Anthropological Sciences (2020) 12: 25

DOI: 10.1007/s12520-019-00950-0

Copyright (C) 2020 Springer-Verlag GmbH Germany. Used by permission.

Submitted 31 December 2018; accepted 16 December 2019; published 13 January 2020. 
plant seeds, and Agave fibers. The macroscopic analysis of the samples fits with the analysis of smaller remains, giving an idea of the meal represented by each coprolite analyzed. We relate these results to previous microbiome studies of coprolite samples from the same archeological site and provide a discussion on the relevancy of studying macro- and microremains that can be applied to microbiome interpretation analysis.

Keywords: Diet, Archaeoparasitology, Coprolites, Pollen

\section{Introduction}

For gut microbiome studies, coprolites from La Cueva de Los Muertos Chiquitos (CMC), Rio Zape, Durango, Mexico, have become model samples for analysis (Hagan et al. 2019; Schnorr et al. 2016; Tett et al. 2019a, b; Tito et al. 2008, 2012). Coprolites from the site have proven preservation of gut microbiome DNA (Hagan et al. 2019; Tett et al. 2019a, b; Tito et al. 2012). Because ancient DNA (aDNA) is so well preserved in these samples, they have been used to assess the comparative success of extraction methods (Hagan et al. 2019). These studies revealed bacterial DNA in distinct coprolite series, a fact that underscores the ideal preservation of CMC coprolites for gut microbiome work. We believe that it is useful to know the dietary background of the site and are presenting evidence from analyses in this paper. We undertook the analysis of dietary remains from 10 additional coprolites selected from remains recovered during a parasitological analysis of 100 coprolites by Morrow (2016). The ten samples were selected to represent separate and distinct grids within the site. Our goal was to define specific "meals" represented by foods in each coprolite. Although we did not analyze the microbiome in this study, we want to highlight the importance of diet analysis for future microbiome studies. Our methods followed that of Reinhard et al. (2006, 2012) and included pollen, phytolith, mycological, starch, and macrofossil study.

Coprolite analyses can provide information on dietary patterns, nutrition, health, and also on the gut microbiome. The composition of macro- and microscopic remains can be essential to understand not only eating habits but also the behavior and health of the population analyzed. These remains can be composed of pollen grains, bone fragments, fibers, starch, and phytoliths. Recently, there have been a great number of studies focusing on the gut microbiome analysis. The microbiome is defined as the biotic and abiotic habitat that comprises the 
community of microorganisms, $\sim 100$ trillion $\left(10^{14}\right)$ microbial cells, associated with the host and environment (Dominguez- Bello and Blaser 2011; Davenport et al. 2017; Schnorr et al. 2016). Regarding the human health, diet and nutritional status can be important and modifiable determinants, and as such can shape the gut microbial communities (David et al. 2014).

Studies on recent gut microbiome populations have correlated diet analysis with the presence of microorganisms. However, although there are studies on the ancient microbiome analysis, few relate to the diet of ancient populations (see Oeggl et al. 2007; Cano et al. 2014; Weyrich et al. 2017). In this study, we highlight the importance of diet and reconstruction of meals of ancient populations. These data could then be used to understand how the microbiome is shaped in ancient populations.

George Armelagos (1994) established three basic goals for paleonutrition, which are relevant to determine which foods define any given population's gut microbiome. They are the range of foods available (menu); which foods were eaten (diet), and the nutritional impact of the diet. Menu, diet, and nutrition of samples from the CMC can be well defined based on botanical analyses of plant remains from the cave (Brooks et al. 1962), studies of quids (Hammerl et al. 2015), and coprolite analysis (Meade 1994). Themenu is mostly defined by analysis of plant remains from the midden (Brooks et al. 1962; Table 1). The breadth of cultivated plants was impressive: twelve varieties of three species of beans (Fabaceae), five varieties (races) of maize (Zea mays), and three species of cultivated squash (Cucurbitaceae) were noted as well as wild gourds (Cucurbita) and squash. Other wild food plants from the midden included acorns (Quercus), piñon pine nuts (Pinus), juniper berries (Juniperus), black walnuts (Juglans), and prickly pear fruits (Opuntia) (Brooks et al. 1962). While Agave was recognized, its dietary use was not defined until extensive studies of quids were completed after the initial analysis (Hammerl et al. 2015). Hammerl et al. (2015) examined 2890 quids of which $80.4 \%$ were derived from chewing roasted Agave heart leaves. The remaining quids were derived from chewing maize husks. Therefore, both Agave and maize were the major sources of food available to the inhabitants of this site.

Forty-three coprolites from the Cueva de Los Muertos Chiquitos were examined by Meade (1994). The macroscopic and pollen evidence 
Table 1 Plant materials from La Cueva de Los Muertos Chiquitos, Durango, Mexico (adapted from Brooks et al. 1962)

\begin{tabular}{|c|c|c|c|c|}
\hline $\begin{array}{l}\text { Location; } \\
\text { depths (in.) }\end{array}$ & $\begin{array}{l}\text { Squash } \\
\text { (Cucurbits) }\end{array}$ & $\begin{array}{l}\text { Corn } \\
\text { (Zea mays) }\end{array}$ & $\begin{array}{l}\text { Beans } \\
\text { (Fabaceae) }\end{array}$ & Other \\
\hline B3 (0-4) & $\begin{array}{l}\text { Cucurbita sp. } \\
\text { Cucurbita pepo } \\
\text { Lagenaria sp. }\end{array}$ & & $\begin{array}{l}\text { Common } \\
\text { Lima } \\
\text { Runner }\end{array}$ & \\
\hline B3 (4-8) & $\begin{array}{l}\text { Cucurbita sp. } \\
\text { C. pepo } \\
\text { Apodanthera sp. } \\
\text { Lagenaria sp. }\end{array}$ & $\begin{array}{l}\text { Husks } \\
\text { Kernels } \\
\text { Cobs }\end{array}$ & $\begin{array}{l}\text { Common } \\
\text { Lima }\end{array}$ & $\begin{array}{l}\text { Acorn } \\
\text { Agave leaf and stem } \\
\text { Grass rhizome fragment } \\
\text { Piñon }\end{array}$ \\
\hline B3 (8-12) & $\begin{array}{l}\text { Cucurbita sp. } \\
\text { C. pepo } \\
\text { C. mixta } \\
\text { Lagenaria sp. }\end{array}$ & $\begin{array}{l}\text { Husks } \\
\text { Kernels }\end{array}$ & $\begin{array}{l}\text { Common } \\
\text { Lima } \\
\text { Runner }\end{array}$ & $\begin{array}{l}\text { Agave stem tips } \\
\text { Bear grass leaf fragment } \\
\text { Cactus roots } \\
\text { Nut fragment, juglans }\end{array}$ \\
\hline B3 (12-16) & $\begin{array}{l}\text { Cucurbita sp. } \\
\text { C. pepo } \\
\text { Apodanthera sp. } \\
\text { Lagenaria sp. }\end{array}$ & $\begin{array}{l}\text { Husk fragments } \\
\text { Cobs } \\
\text { Cob nubbins } \\
\text { Kernels }\end{array}$ & $\begin{array}{l}\text { Common } \\
\text { Lima } \\
\text { Runner }\end{array}$ & $\begin{array}{l}\text { Acorns } \\
\text { Agave leaf fragment } \\
\text { Piñon }\end{array}$ \\
\hline B3 (16-20) & $\begin{array}{l}\text { Cucurbita sp. } \\
\text { C. pepo } \\
\text { Apodanthera } \\
\text { Lagenaria }\end{array}$ & $\begin{array}{l}\text { Stem section } \\
\text { Husk fragments } \\
\text { Cob } \\
\text { Kernels } \\
\text { Teonsite- corn hybrid }\end{array}$ & $\begin{array}{l}\text { Common } \\
\text { Runner }\end{array}$ & $\begin{array}{l}\text { Acorns } \\
\text { Agave leaf fragment } \\
\text { Cactus base, Echinocerus } \\
\text { Reed fragment } \\
\text { Gall } \\
\text { Tithonia } \\
\text { Yucca root fragment }\end{array}$ \\
\hline B4 (12-16) & $\begin{array}{l}\text { Cucurbita sp. } \\
\text { C. pepo } \\
\text { Lagenaria sp. }\end{array}$ & & Common & Cactus \\
\hline B4 (16-20) & $\begin{array}{l}\text { Cucurbita sp. } \\
\text { C. pepo } \\
\text { Apodanthera sp. } \\
\text { Lagenaria sp. }\end{array}$ & & Common & Cactus \\
\hline B4 (20-24) & $\begin{array}{l}\text { Cucurbita sp. } \\
\text { C. pepo } \\
\text { Apodanthera sp. } \\
\text { Lagenaria sp. }\end{array}$ & & Common & \\
\hline D2 (0-12) & Cucurbita sp. & & Lima & \\
\hline D2 (12-16) & $\begin{array}{l}\text { Cucurbita sp. } \\
\text { C. pepo }\end{array}$ & & Common & \\
\hline
\end{tabular}

of foods from the coprolites includes fruits from ground cherry (Physalis), maize (Z. mays), sunflower (Helianthus), pigweed (Amaranthus), and quinoa goosefoot (Chenopodium). Far more common than seeds, course fiber composed the majority of the coprolites and accounted for $60 \%$ of the average coprolite weight. Agave and prickly pear epidermis were found. Entire swallowed quids were evident in some of the coprolites. The coprolite analysis showed that $77 \%$ of 
coprolite samples contained Agave fiber and 57\% contained maize kernels. The total of $17 \%$ of samples contained goosefoot (Chenopodium) fruits; 13\% contained sunflower achenes, 10\% wild grass (Poaceae) caryopses, and 7\% groundcherry (Physalis) fruits and squash seeds. Traces of several other plants were found, of which amaranth (Amaranthus), prickly pear, purslanes (Portulaca), sumac (Rhus), juniper, and dropseed grass (Sporobolus) were identified. Animal remains were found in $77 \%$ of the samples and included mammal bone, fish bone, fish scales, and grasshopper exoskeleton. These studies show that a wide variety of foods were available. However, the actual diet was composed mostly of maize, Agave, and small animals.

\section{Materials and methods}

\section{Archeological site: La Cueva de Los Muertos Chiquitos}

The site La Cueva de Los Muertos Chiquitos is located within the Rio Zape Valley, in Durango, Mexico. The population that temporarily resided there was comprised by the Loma San Gabriel, between 1200 and 1400 years ago (Hammerl et al. 2015; Morrow and Reinhard 2016). The valley is represented by a series of caves used by the Loma San Gabriel; their subsistence composed of a mixture of agricultural production and hunting-gathering that fluctuated seasonally (Brooks et al. 1962; Morrow and Reinhard 2016).

The site was excavated by Richard and Sheilagh Brooks in 1957 and 1960. The cave is at $1800 \mathrm{~m}$ in elevation, about $18.5 \mathrm{~m}$ wide, and averages $9 \mathrm{~m}$ deep (Hammerl et al. 2015). Brooks et al. (1962) described the excavation records for the latrine deposits where the coprolites were excavated. According to Brooks et al. (1962), there were two parallel trenches (trenches A and B) that measured $5 \mathrm{ft}$ wide and $23 \mathrm{ft}$ long. There was an additional excavation, on trench $\mathrm{C}$ parallel to both trenches, that measured $2 \frac{1}{2} \mathrm{ft}$ wide. Coprolites were found in grids A2, B2, B3, B4, C1, C2, D1, and D2.We selected coprolites from grids B3, B4, and D2 for processing (Table 2). The excavation revealed several botanical artifacts, the skeletons of 14 children, some adult body fragments, around 500 coprolites, and over 2000 quids that were beneath the adobe floor (Morrow and Reinhard 2016). 
Table 2 Samples analyzed in this study

\begin{tabular}{lccccc} 
Number & Sample ID & $\begin{array}{c}\text { Lycopodium } \\
\text { spores counted }\end{array}$ & Provenience & Level (in.) & Host type \\
\hline 1 & Zape-1 & 19 & B3 & $0-3$ & Human \\
2 & Zape-13 & 86 & B3 & $4-8$ & Probably human \\
3 & Zape-30 & 46 & B3 & $8-12$ & Human \\
4 & Zape-43 & 32 & B3 & $12-16$ & Human \\
5 & Zape-46 & 252 & B3 & $16-20$ & Human \\
6 & Zape-66 & 84 & B4 & $12-16$ & Human \\
7 & Zape-87 & 79 & B4 & $16-20$ & Human \\
8 & Zape-92 & 100 & B4 & $20-24$ & Dog \\
9 & Zape-98 & 87 & D2 & $0-12$ & Human \\
10 & Zape-100 & 171 & D2 & $12-16$ & Human \\
\hline
\end{tabular}

\section{Coprolite processing and sample analysis}

Coprolites from CMC are archived by the Pathoecology Laboratory in the School of Natural Resources at the University of Nebraska. This is a filtered air, positive pressure facility, free of contaminants smaller than a micrometer. For parasitological analysis by Morrow and Reinhard (2018), 100 coprolites from this collection were given an individual "Sample Designation" numbers. The samples were weighed, photographed, and placed into individually labeled plastic zippered bags. To reduce the retention of contaminants, the surfaces of the coprolites were abraded using sterile, stiff brushes. Nitrile gloves were worn during cleaning to prevent modern contamination of material. Each coprolite was placed into a clean secondary analysis bag. Then, a subsample was separated from each coprolite and weighed. These subsamples were rehydrated with $0.5 \%$ trisodium phosphate for 24 $\mathrm{h}$. Then the rehydrated samples in fluid were disaggregated with a magnetic stirrer. The color of the rehydrated material was recorded. During disaggregation, Lycopodium spore tablets (Batch \# 124961; containing approximately 12,500 spores/tablet) were added to each subsample at one tablet per gram of subsample (Warnock and Reinhard 1992; Morrow and Reinhard 2018). The tablets in rehydration solutions were in dilute hydrochloric acid $(\mathrm{HCl})$ within sterilized 50 $\mathrm{ml}$ plastic beakers and rinsed into each beaker of disaggregated material (Stockmarr 1971). 
In this study, we used 10 coprolite samples that were first processed for parasite analysis as described by Morrow and Reinhard (2016), and Morrow and Reinhard (2018). Macroscopic remains were separated from microscopic remains, and stored after the processing in whirlpak bags for future analysis. Parasite data allowed the interpretation of which host the coprolites belonged to (Table 2). Host specific human parasites, for example, Enterobius vermicularis, were used to identify coprolites as human; coprolites that contained zoonotic parasites were not considered human. Despite the animal origin, Zape92 was included in the analysis as it contained Physaloptera sp. eggs and based on that analysis, we determined that it was probably from a canid host. The diet analysis of the canid coprolite might provide information regarding human foods scavenged by the canid, as they probably co-occurred in the site with humans.

After parasite analysis and quantification by Morrow and Reinhard (2018), aliquots of each sample were reserved for acetolysis process for pollen analysis. A total of 10 coprolite samples were selected and processed for pollen extraction. The samples were screened through a $250-\mu \mathrm{m}$ mesh screen to separate macroscopic remains from microscopic remains. Macroscopic remains were transferred to clean, appropriately labeled filter paper and dried. For our analysis, dried materials were later examined using an Olympus SZ-PT dissection microscope to assess dietary and taphonomically significant macrofossils.

Next, we processed the microremains for pollen analysis as described by Reinhard et al. (2006) and Reinhard et al. (2012). The microscopic remains were washed in distilled water. A "wash" begins with $15 \mathrm{ml}$ of distilled water is added to a sample tube. The sample is mixed with the water on a vortex stirrer. Then 30 more ml of distilled water is added to the tube. The tube is centrifuged and the supernatant poured off, completing the wash. After the distilled water wash, the samples are washed with glacial acetic acid. Since acetolysis solution reacts violently to water, at least one glacial acetic acid wash is necessary. We mixed the acetolysis solution of 9 parts acetic anhydride and 1-part sulfuric acid. The microscopic remains were mixed with the solution with a vortex stirrer and the tube was placed in a water bath at $99{ }^{\circ} \mathrm{C}$ for $10 \mathrm{~min}$. After centrifugation, the tubes are poured into a hazardous waste container. After another glacial acetic acid wash, we washed the samples multiple times in distilled water until 
the supernatant was clear. The sediment was transferred to a 2-dram glass vial in glycerin for archival storage. At this stage, the chemical processing necessary for pollen analysis was done. Acetolysis dissolves cellulose, chitin, and other materials, thereby concentrating the pollen. Acetolysis also darkens the pollen which makes pollen morphology apparent. Samples of the residue were pipetted onto microscope slides, and prepared for microscopy by mixing a small amount of concentrated residue, with a drop of glycerin on a clean glass microscope slide, and covered with $\# 1$ a $22 \mathrm{~mm} \times 22 \mathrm{~mm}$ cover slip. These residues were scanned for pollen grains and also for starch, phytoliths, and other dietary microfossils.

After this step, microscopic analysis of all microremains was performed using a Nikon (Model: Eclipse H55oS) compound microscope equipped with Infinity Image Capture camera. We analyzed the presence and absence of phytoliths, starch, and other microremains, and counted the number of pollen grains to calculate the concentration of pollen grains/gram. The analysis of fermented/non fermented starch was done comparing to a previous study by Vinton et al. (2009). Subsequently, for scanning electron microscopy analysis, each sample was processed by dehydration using $100 \%$ ethanol, and fixed on an aluminum stub that was sputter coated with chromium. Samples were then analyzed using a Field Emission Scanning Electron Microscope (Hitachi S470o Field Emission SEM), and images were captured using the built-in software provided.

For microremains quantification, Lycopodium spore tablets (Batch no. 124961, Dept. of Quaternary Geology, University of Lund, Lund, Sweden) were added by Morrow and Reinhard (2018). Pollen grains were counted along with Lycopodium spores (each tablet contains approximately 12,500 spores; Table 2 ). In order to estimate the amount of microfossil remains, we used the following formula:

$$
\begin{array}{ll}
\text { Microfossil concentration }=[(p / m) \times a]=w \\
p & \text { number of microfossils counted } \\
m & \text { number of marker grains (Lycopodium spores) counted } \\
a & \text { number of Lycopodium spores added to the sample } \\
w & \text { total weight of sample prior to rehydration }
\end{array}
$$


Macrofossil remains were separated into five mesh categories: > 2mm; 1-2mm; 0.5-1.0 mm; 0.25-0.5 mm; < 0.25mm. The analysis of macroscopic remains of each sample selected for acetolysis was done using a stereomicroscope to verify the presence of plant and animal materials.

We analyzed and defined the meals based on the analyses of pollen passage through digestive tracts (Kelso and Solomon 2006; Dean 2006). Sobolik (1994) established parameters for determining how many days passed since the ingestion of a polliniferous food. Reinhard (1993) analyzed the passage of foods through a Peruvian mummy intestine and found three distinct associations of macroscopic and microscopic foods in different parts of the colon. Similarly, Reinhard and Hevly (1991) found two distinct samples from a Southwestern mummy. Both mummy analyses show that elements of one meal overlap with another. However, there is a dominance of the components of each meal compared with traces of other meals. Therefore, for this paper, we define the dominant foods as one meal, and trace components as residue of a second meal.

Pollen analysis presents a degree of ambiguity with regard to dietary interpretation. Several authors have addressed pollen interpretation from coprolites. We followed the suggestions of Ancestral Pueblo analysts who encountered pollen types and counts similar to those of CMC (Reinhard et al. 2006, 2012). Low pollen counts for wind-pollinated types are most likely environmental. However, when such pollen is pristine and present in large numbers, the pollen was more likely to be ingested. Insect-pollinated types are more likely to have a dietary origin when they appear in coprolites. Maize is a special type in that pollen does not disperse far from the source plant. Therefore, large amount of maize in coprolites signals purposeful ingestion. In Table 3, values with asterisk are likely to be dietary.

\section{Results}

\section{Macro- and microscopic findings in coprolites}

The pollen diversity and concentrations for each sample are displayed in Table 3. Table 4 shows the number of pollen grains counted 
Table 3 Identification of pollen species and other microscopic remains in each sample analyzed

\begin{tabular}{|c|c|c|c|c|c|c|c|c|c|c|c|}
\hline $\begin{array}{l}\text { Concentration } \\
\text { of microscopic } \\
\text { remains/coprolite }\end{array}$ & Zape-1 Z & Zape-13 & Zape-30 & Zape-43 & Zape-46 & Zape-66 & Zape-87 & Zape-92 & Zape-98 & Zape-100 & $\begin{array}{r}\text { Total } \\
\text { concentration }\end{array}$ \\
\hline Ustilago maydis (Corn smut & ג) 0 & 0 & 0 & 0 & 0 & 0 & $32,278^{*}$ & 125 & 575 & 0 & 32,978 \\
\hline Zea mays pristine & $53,289 *$ & 0 & 0 & 0 & 0 & 595 & 949 & 125 & 718 & 1389 & 57,065 \\
\hline Z. mays Smashed/folded & $161,842^{*}$ & 436 & 0 & 0 & 0 & 0 & 0 & 0 & 0 & 146 & 162,424 \\
\hline Zea mays shredded & $113,158^{*}$ & $\quad 0$ & 0 & 0 & 0 & 0 & 0 & 0 & 0 & 219 & 113,377 \\
\hline Quercus & 1316 & 145 & 272 & 0 & 298 & 0 & 633 & 750 & 1437 & 0 & 4851 \\
\hline Ephedra & 0 & 0 & 0 & 0 & 0 & 0 & 949 & 0 & 0 & 73 & 1022 \\
\hline Artemisia & 0 & 145 & 272 & 0 & 0 & 149 & 0 & 0 & 0 & 0 & 566 \\
\hline Brassicaceae & 0 & 0 & 0 & 0 & 0 & 0 & 0 & $125^{\star}$ & $575^{\star}$ & 0 & 700 \\
\hline Chenopodium & 0 & 145 & 272 & 0 & 50 & 149 & 0 & 0 & $2011^{*}$ & 292 & 2919 \\
\hline Poaceae & 0 & 145 & 0 & 0 & 50 & 0 & 0 & 0 & 287 & 73 & 555 \\
\hline Helianthus & 0 & 436 & 272 & 0 & 99 & 0 & 158 & 0 & $1580^{*}$ & 0 & 2545 \\
\hline Soledago & 0 & 0 & 272 & 0 & 0 & 0 & 0 & 0 & 0 & 0 & 272 \\
\hline Rosaceae & 1316 & 0 & 0 & 0 & 50 & 0 & 0 & 0 & 0 & 0 & 1366 \\
\hline Pinus & 0 & 145 & 543 & 0 & 298 & 595 & 316 & 3000 & 862 & 146 & 5905 \\
\hline Solanaceae & 0 & 145 & 0 & 0 & 0 & 0 & 0 & 0 & $8046^{*}$ & 0 & 8191 \\
\hline Senecio & 0 & 0 & 0 & 0 & 0 & 0 & 0 & 0 & 144 & 73 & 217 \\
\hline Cucurbitaceae & 0 & 0 & 0 & 0 & 0 & 0 & 0 & 0 & 0 & $439^{*}$ & 439 \\
\hline Malvaceae & 0 & 0 & 0 & 0 & 0 & 0 & 0 & 0 & 0 & $73^{*}$ & 73 \\
\hline Unident & 658 & 0 & 543 & 391 & 149 & 744 & 791 & 500 & 1006 & 146 & 4928 \\
\hline
\end{tabular}

*Values that are likely to be dietary

Table 4 Number of pollen grains counted per coprolite sample

Pollen grains counted

Zape-1 Zape-13 Zape-30 Zape-43 Zape-46 Zape-66 Zape-87 Zape-92 Zape-98 Zape-100

\begin{tabular}{lcccccccccc}
\hline Ustilago maydis (Corn smut) & 0 & 0 & 0 & 0 & 0 & 0 & 204 & 1 & 4 & 0 \\
Zea mays Pristine & 81 & 0 & 0 & 0 & 0 & 4 & 6 & 1 & 5 & 19 \\
Z. mays Smashed/folded & 246 & 3 & 0 & 0 & 0 & 0 & 0 & 0 & 0 & 2 \\
Zea mays Shredded & 172 & 0 & 0 & 0 & 0 & 0 & 0 & 0 & 0 & 3 \\
Quercus & 2 & 1 & 1 & 0 & 6 & 0 & 4 & 6 & 10 & 0 \\
Ephedra & 0 & 0 & 0 & 0 & 0 & 0 & 6 & 0 & 0 & 1 \\
Artemisia & 0 & 1 & 1 & 0 & 0 & 1 & 0 & 0 & 0 & 0 \\
Brassicaceae & 0 & 0 & 0 & 0 & 0 & 0 & 0 & 1 & 4 & 0 \\
Chenopodium & 0 & 1 & 1 & 0 & 1 & 1 & 0 & 0 & 14 & 4 \\
Poaceae & 0 & 1 & 0 & 0 & 1 & 0 & 0 & 0 & 2 & 1 \\
Helianthus & 0 & 3 & 1 & 0 & 2 & 0 & 1 & 0 & 11 & 0 \\
Soledago & 0 & 0 & 1 & 0 & 0 & 0 & 0 & 0 & 0 & 0 \\
Rosaceae & 2 & 0 & 0 & 0 & 1 & 0 & 0 & 0 & 0 & 0 \\
Pinus & 0 & 1 & 2 & 0 & 6 & 4 & 2 & 24 & 6 & 2 \\
Solanaceae & 0 & 1 & 0 & 0 & 0 & 0 & 0 & 0 & 56 & 0 \\
Senecio & 0 & 0 & 0 & 0 & 0 & 0 & 0 & 0 & 1 & 1 \\
Cucurbitaceae & 0 & 0 & 0 & 0 & 0 & 0 & 0 & 0 & 0 & 6 \\
Malvaceae & 0 & 0 & 0 & 0 & 0 & 0 & 0 & 0 & 0 & 1 \\
Unident & 1 & 0 & 2 & 1 & 3 & 5 & 5 & 4 & 7 & 2 \\
\hline
\end{tabular}


Table 5 Results for the analysis of the presence $(\mathrm{P})$ and absence (A) of phytolyths, starch, and plant tissue of each coprolite. Altered refers to morphologies that reflect cooking (bean) or possibly fermentation (corn)

\begin{tabular}{lccccccc}
$\begin{array}{l}\text { JJM } \\
\text { number }\end{array}$ & Fermented & $\begin{array}{c}\text { Bean starch } \\
\text { Fermented }\end{array}$ & Fermented & $\begin{array}{c}\text { Non } \\
\text { Fermented }\end{array}$ & $\begin{array}{c}\text { Prickley pear } \\
\text { phytolith }\end{array}$ & $\begin{array}{c}\text { Agave } \\
\text { Phytolith }\end{array}$ & $\begin{array}{c}\text { Agave } \\
\text { plant tissue }\end{array}$ \\
\hline Zape-1 & A & A & A & A & A & A & A \\
Zape-13 & A & A & A & A & A & A & A \\
Zape-30 & P & P & P & P & P & P & P \\
Zape-43 & A & A & A & A & A & A & P \\
Zape-46 & A & A & P & A & A & A & P \\
Zape-66 & P & A & A & P & A & A & P \\
Zape-87 & A & P & A & P & A & P & A \\
Zape-92 & A & A & A & A & A & A & P \\
Zape-98 & A & A & A & A & A & A & P \\
Zape-100 & A & A & A & A & A & A & A \\
\hline
\end{tabular}

for each sample. The presence and absence of starch, fungus, and phytoliths in each sample are shown on Table 5 .

The macroscopic remains on sample Zape-1 were compressed plant tissue processed to less than $1 \mathrm{~mm}$ in largest dimension. The compression resulted from digestive constriction. This sort of coprolite residue poses significant challenge for identification. However, the microscopic remains revealed an abundance of maize pollen (Fig. 1a). Subsequent pollen analyses showed that a total of 328,289 maize pollen grains per gram were present in the sample, ranging from pristine pollen to compressed and then to completely shredded. The presence of a single pore allowed for the identification and quantification of maize pollen grains, as the absence of the pore could allow for the misidentification (Reinhard et al. 2006). The compressed type of pollen presented the highest concentration number in Zape-1, with 161,842 grains of compressed maize grains/gram of coprolite, and the compression could indicate some sort of preparation. Other types of pollen were also identified in Zape-1, such as oak (Quercus; concentration 1316 grains/gram coprolite); Rosaceae (1316 grains/ gram); and types of pollen that were not possible to be identified (unident 658 grains/ gram). The meal represented by Zape-1 was composed on maize pollen in condition ranging from pristine to shredded (see Table 6 for a summary of the meals for each sample). 


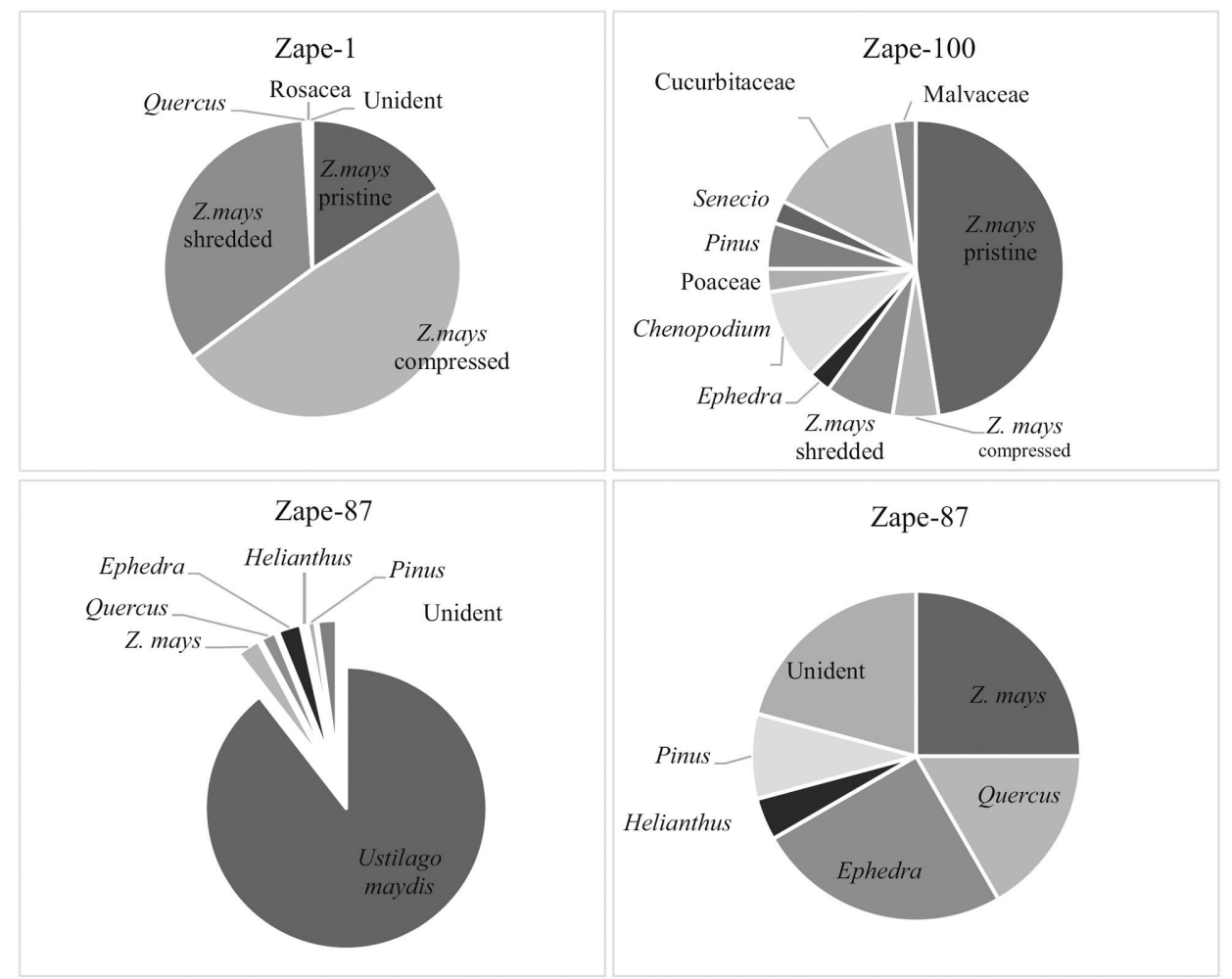

Fig. 1 Contrast of concentration of pollen/gram in three different coprolite samples. a Zape-1. b Zape-10o. c Zape-87 with the concentration of Ustilago maydis. d Zape87 without $U$. maydis concentration.

Table 6 A summary of the food items identified in each sample analyzed

Sample number Food items in each meal

Zape-1 Maize pollen

Zape-13 Juniper berries, pinole, maize and juniper

Zape-30

Zape-43

Zape-46

Zape-66

Zape-87

Zape-92

Zape-98

Zape-100
Prickly pear, Agave, maize, beans and rodent bones

Finely ground maize, fruit fragments, rodent bones.

Agave quid fiber, maize

Large kernel, finely milled maize, rodent bones. Meal composed by large kernel corn, milled maize with rodents.

Milled maize, squash seed, Agave phytoliths. Baked Agave hearts.

Larval insect fragments, lizard scales.

Milled maize, Agave phytoliths, ground maize kernels.

Cooked prickly pear pads, tomatillo, rodent bones. 


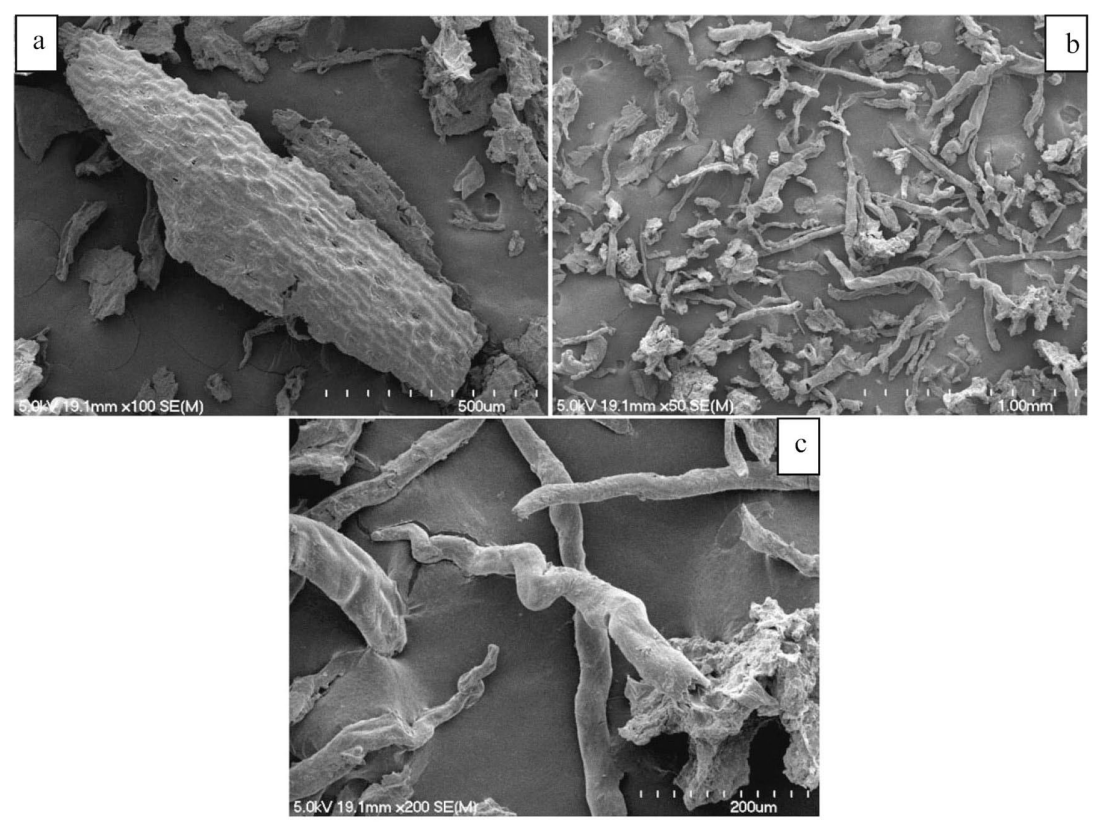

Fig. 2 Microremains from Zape- 13. a Helianthus (sunflower) achene fragment. b Plant fragments from Juniper. c Closer look on the Juniper fragments.

For Zape-13, the diversity of plant and pollen was different than Zape-1: traces of sunflower achenes were evident in the macroscopic remains, with the concentration of 436 pollen grains/gram (Fig. 2a). Juniper berries are represented by fragmented juniper cones, seeds, and delicate terminal branch foliage (Fig. 2b, c). Brown maize kernels milled to 0.5-1.0 $\mathrm{mm}$ were the most common materials. In microremains, the evidence of maize was in lower concentration (436 grains/ gram); concentration of oak (Quercus), sage (Artemisia), quinoa goosefoot (Chenopodium), pine (Pinus), nightshade (Solanaceae), and wild grass (Poaceae) was 145 grains/gram of coprolite. The brown color of maize kernels indicates a color variant cultivated by the cave inhabitants. It is likely that the fresh color was a reddish brown. The meal represented was composed of a mix of pinole, maize, and juniper.

The microscopic findings for Zape-3o included prickly pear and Agave phytoliths, maize starch, and bean starch. The concentration of pollen grains was lower when compared with the other previous samples analyzed, with a higher concentration of Pinus (543 grains/ gram). Macrofossils included ground yellow maize, small mammal 


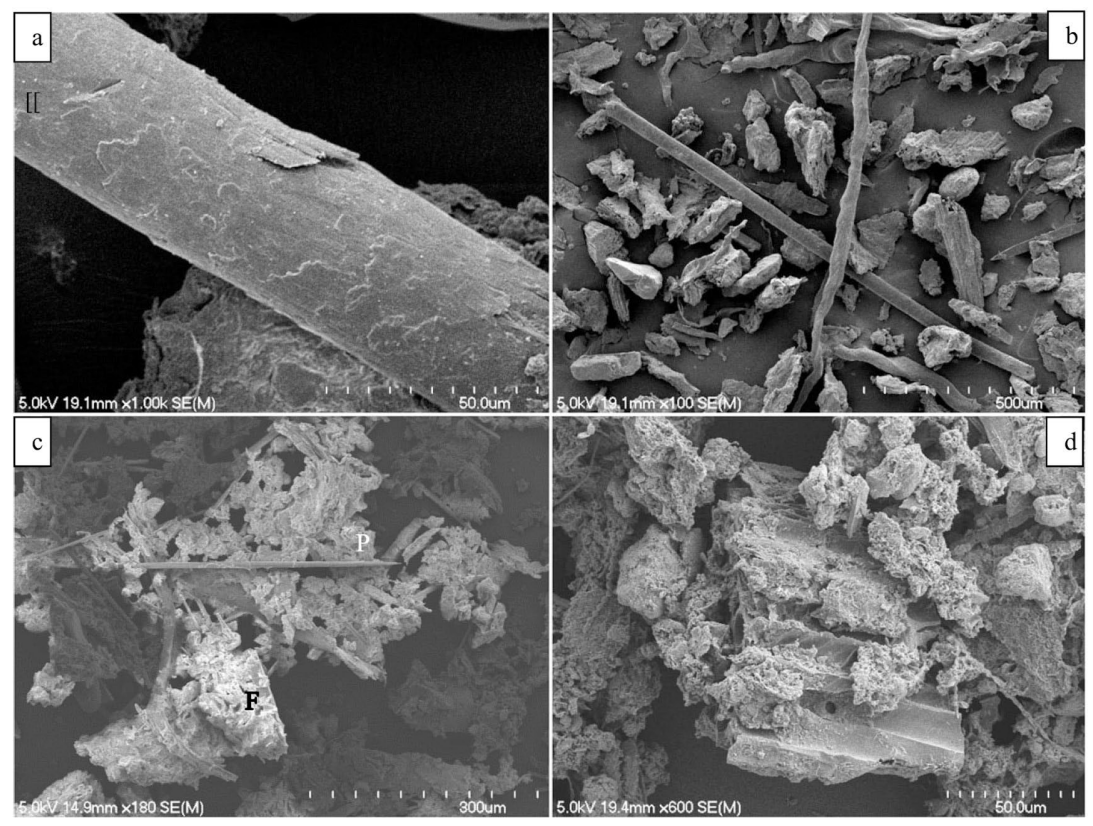

Fig. 3 Microremains from different samples. a Hair from Zape-30. b Hair with miscellaneous, fragmented plant remains from Zape-30. c Phytoliths (P) and fibers (F) from Zape-46. d Xylem stem section from Zape-43.

bone, and a dominance of Agave quid fiber. Also, an unidentified hair was found (Fig. 3a).

We found in Zape-43 a smaller concentration of pollen, with 391 grains/gram of unidentified pollen. Traces of unidentified fruit fragments (Fig. 4a, b) and seed were found microscopically (Fig. 4c, d) and other plant fragments, such as xylem (Fig. 3d), show that these items were also part of the meal ingested with maize and rodents, which were found macroscopically in that sample. The presence of fruit fragments and seeds are relevant for reconstructing the meals.

Agave quid fiber was represented in Zape-46: for both macroscopic and microscopic remains (Fig. 3c). By weight, the sample is dominated by milled yellow maize kernels. This suggests that the meal was composed of Agave and maize.

For Zape-66, we found macroscopic evidence of large kernel corn and evidence of very finely milled yellow maize (595 grains/gram; Fig. 5a, b) and starch, that was likely fermented (Fig. 5d). The starch grains were identical to those experimentally fermented and described by Vinton et al. (2009). The morphology of the small mammal bone suggests it was crushed and the brown coloration suggests that it 


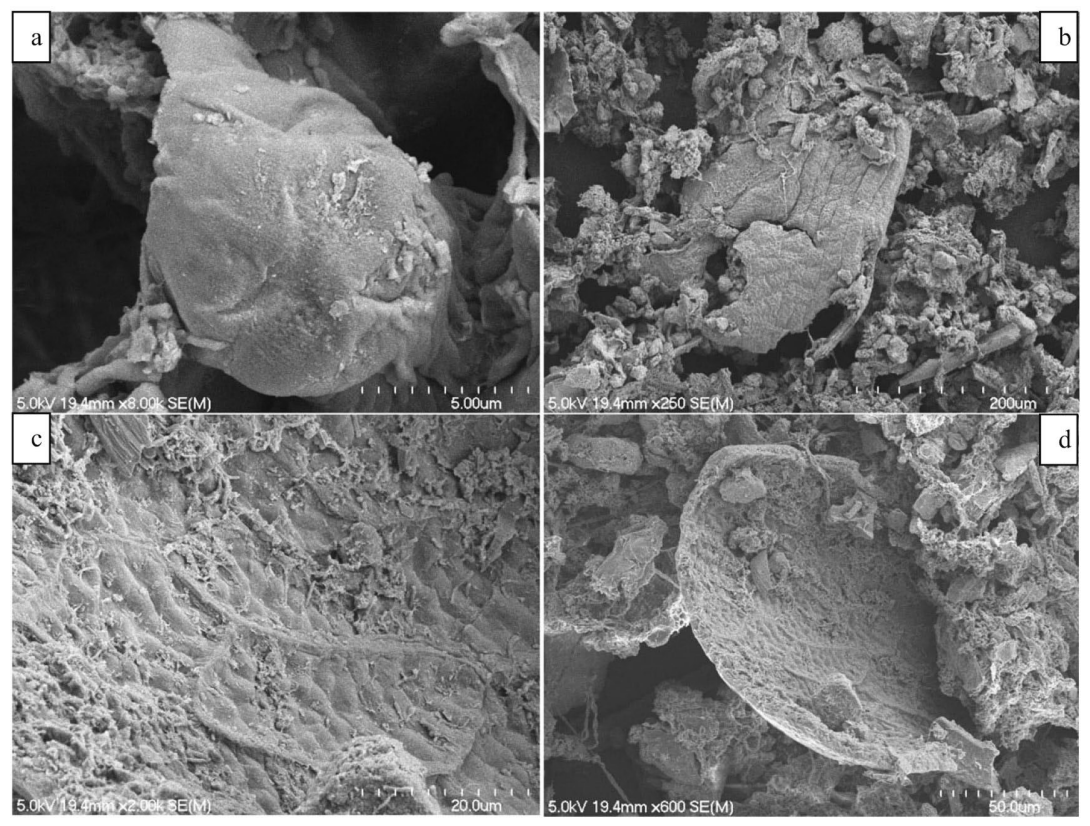

Fig. 4 Fruit fragments (a, b) and seed coat fragments (c, d) from Zape-43.

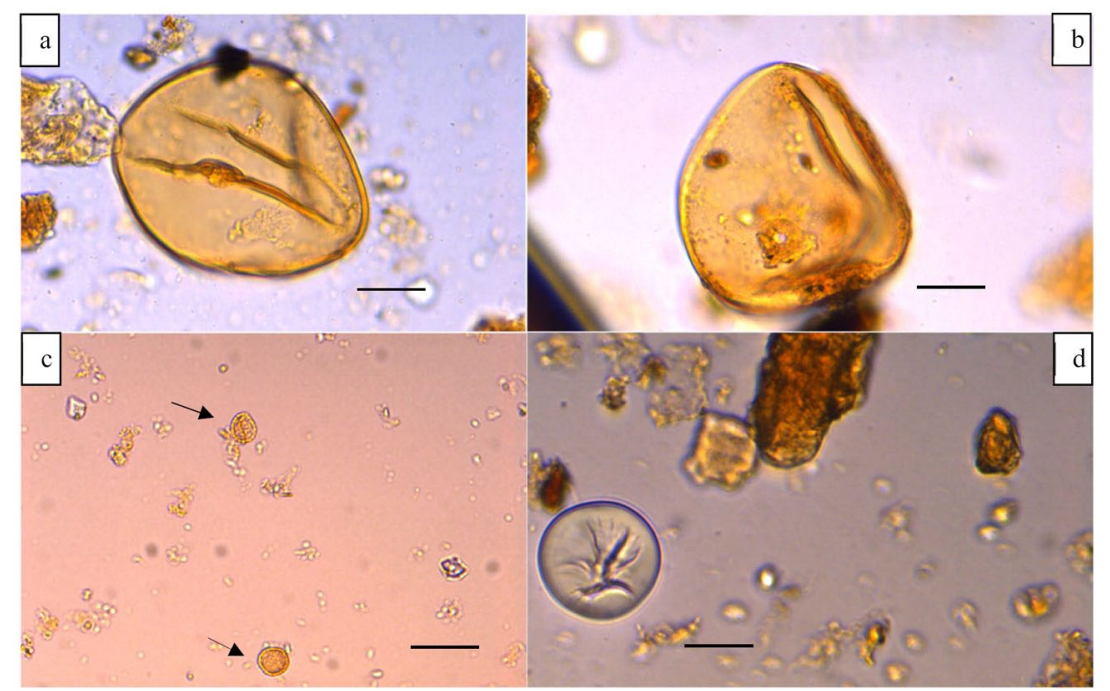

Fig. 5 Corn microremains from Zape samples. a Maize pollen from Zape-66 ( $\times$ 6o). b Maize pollen with visible pore from Zape-66 (× 60). c $U$. maydis from Zape 87 ( $\times$ 6o). d corn starch from Zape-66. Scale bar, $20 \mu \mathrm{m}$.

was cooked. This suggests that the meal was composed of fresh large kernel corn and milled maize cooked with rodents. This is likely one meal, or two separate meals eaten near the same time, that is represented by this sample. 
Macroscopically, Zape-87 is composed of finely milled maize and one squash seed with very fine fiber. Microscopic traces of maize starch, bean starch, and traces of Agave phytoliths were found. Microscopically, spores of Ustilago maydis (corn smut) were abundant (Fig. 5c). This meal was composed of ground maize kernels (Fig. 1C, d). The Agave phytoliths represent Agave hearts. It is possible that some phytoliths could have been ingested if the dentition was used to strip fibers. However, the prevalence and microscopic volume of phytoliths signals a dietary source. The presence of one squash seed is not an indication that it was part of the meal, as only one seed was found.

Parasite analysis of Zape-92 by Morrow (2016) indicated that this sample was deposited by a dog. Macroscopic analysis indicated that it was composed almost exclusively of larval insect fragments, with distinct characters related to arthropods, such as the presence of spiracles and mandible. The larval fragments are soft bodied with exoskeleton heads most likely in caterpillars or grubs. The soft body segments have bilateral spiracles. The anterior exoskeleton fragments include mandibles and legs. Also present are lizard scales.

Macroscopically, Zape-98 is composed of finely milled maize with very fine fiber. Microscopic traces of Agave phytoliths were found. Regarding pollen, this sample had the biggest diversity of pollen, ranging from a high concentration of Solanaceae pollen (8046 grains/gram) to Chenopodium (2011 grains/gram), Helianthus (1580 grains/gram), and maize (718 grains/gram). This meal was composed of ground maize kernels.

The meals that composed Zape-10o was characterized by the presence of Prickly pear pads and Physalis (groundcherry, tomatillo) fruits. In addition, traces of maize, cotton (Fig. 6a, b), and squash (Fig. 6d, c) pollen were found. This suggests that flower blossoms could have been included in the stew as they are entomophilous (Fig. 1b).

\section{Discussion}

In this paper, we discussed the meals from different coprolites collected in 1957 and 1960. The macroscopic remains of the samples reinforce the microscopic analysis, giving a general idea of the meal represented by the coprolites. In the 10 coprolites, the most common type of food that consumed was maize (Fig. 7). We call attention to Zape-1 

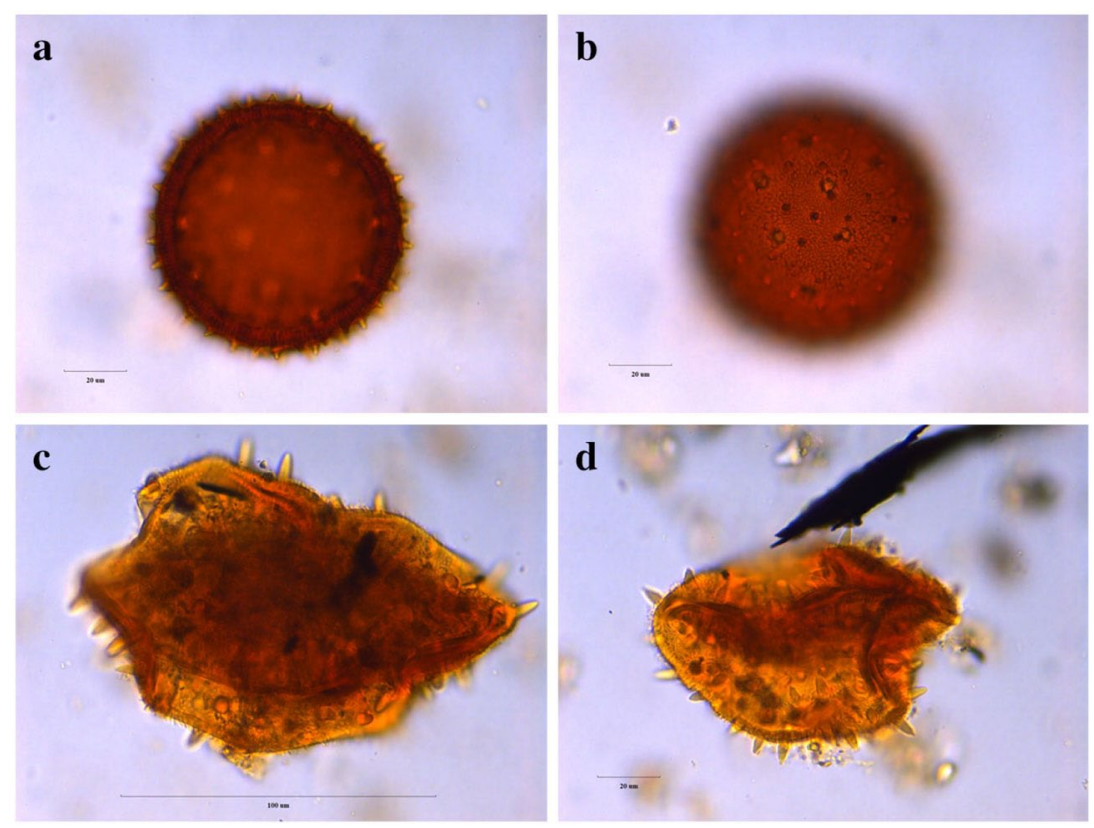

Fig. 6 Pollen from Zape-10o. a Malvaceae in $\times 60$ equatorial view. b Malvaceae in $\times$ 60 polar view. c Cucurbitaceae in $\times 60$. d Cucurbitaceae in $\times 40$. Scale bar, $20 \mu \mathrm{m}$.

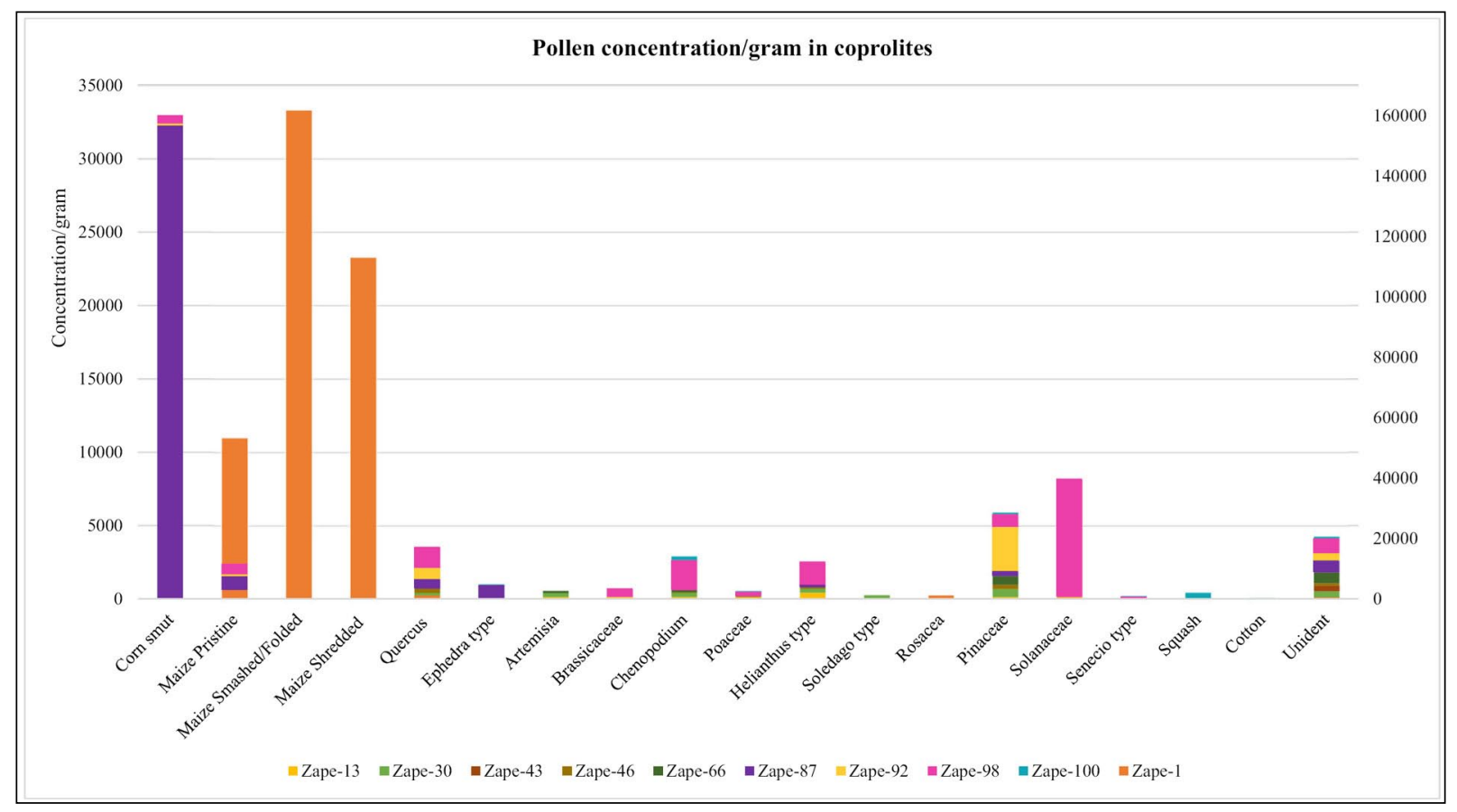

Fig. 7 Concentration/gram of different pollen species in each sample of coprolite. 
that was mainly composed of maize pollen grains. The presence of these pollen grains indicates that possibly the pollen was collected and used as food, as most of the grains were shredded or compressed. A study by Clah (1974 apud Linskens and Jorde 1997) demonstrates the consumption of maize pollen by Navajo women and children. They collected the pollen grains by shaking the tassels, drying the grains, and kneading them as a dough to be consumed (Linskens and Jorde 1997). The great amount of pollen grains in this sample could indicate that possibly the pollen grains were also part of the diet.

The identification of plant remains by Brooks et al. (1962) provided evidence that bean, squash, and corn were being grown and consumed by the population that inhabited the cave. The coprolite analyses have confirmed that the individuals would feed upon those plants that were cultivated in the region. The carbohydrates present in their meals were mainly composed of maize, squash, and Agave. Figure 5 shows different kinds of preparation of corn, ranging from pollen to corn smut and fermented starch. Also, squash flowers were part of their diet as well, due to the presence of pollen grains in Zape-10o (Fig. 6). Although low in protein and carbohydrates, squash flowers are high in calcium, vitamins A, C, and $\mathrm{K}$, and also iron (Saboo et al. 2013). Based on the analysis, we can conclude that corn was the main source of carbohydrates and fiber. Corn and beans (which were present in Zape-30) are sources of calcium, iron thiamin, niacin, and vitamin B6 (Cerqueira et al. 1979).

However, as seen by the results of the macroscopic remains, there were other food items that were part of the meal, such as the presence of Juniper, rodent bones, and possibly insects; thus, not only were carbohydrates the main component of their diet but also rodents were a source of protein. We call attention to the insect larvae identified in the macro remains of a canid coprolite (Zape-92). We based the identification of the canid host on the presence of Physaloptera sp., a canid-specific parasite (Morrow 2016). Studies on the effects of agriculture and ancient dog diets have shown a genetic adaptation to the starch consumption (Arendt et al. 2016), probably due to the consumption of human leftovers. A previous study on free-ranging domestic dogs in agropastoral rural areas in Zimbabwe has shown that dogs are primarily scavengers of human and animal waste (Butler and Du Toit 2002). The occurrence of insect larvae in the canid coprolite could indicate that the canid was feeding on leftovers from a meal of 
caterpillars. Also, other studies have shown that the most common insect consumed in the region in Mexico is from the family Hepialidae, commonly called the ghost moth (Gómez et al. 2016). There are 549 species of edible insects recorded in Mexico, and the consumption of Hepialidae larvae is the most common among indigenous people (Gómez et al. 2016); however, we need further analyses to identify the larvae remains. Ingestion of insects has not only been recorded in recent indigenous communities but also in early human populations. Previous studies have indicated that insects have been a source of food since early hominids (Backwell and D'Errico 2001; Sponheimer et al. 2005; Ramos-Elorduy 2009; Van Huis 2017).

In the analysis, we found that preparation of maize was done in different ways. Spores of $U$. maydis were found in three samples (Zape-87, Zape-92, and Zape-98), which signals the consumption of huitlacoche, common among the Tarahumara (Fig. 5c; QuiñónezMartínez et al. 2014). The Tarahumara are a Ute-Aztecan tribe that lives in the Sierra Madre Occidental Mountains, in Northern Mexico (Cerqueira et al. 1979; Monárrez-Espino et al. 2001). The coprolites from CMC are located in Durango, Mexico, which could indicate that the consumption of this fungus was also part of the feeding habits of the Loma San Gabriel. U. maydis is a biotrophic fungus that causes gall and therefore crop spoilage. This fungus has been a source of food since the pre- Columbian period (Ruiz-Herrera and MartínezEspinoza 1998; Juárez-Montiel et al. 2011). According to a study by Juárez-Montiel et al. (2011), huitlacoche contains amino acids, such as lysine and leucine, and is also rich in carbohydrates, with high content of glucose and fructose. Also, the formation of tumors in the corn induces the formation of anthocyanin pigment in the host plant tissue. The ingestion of anthocyanins has anti-inflammatory, anticarcinogenic, antidiabetic, anti-obesity, and cardioprotective properties (Patel 2016).

Evidence of historic Tarahumara food ways is also found in Zape87 and Zape-98, with the presence of ground maize kernels that resemble Tarahumara pinole. In general, Pinole refers to any of a variety of parched or roasted corn, ground into a flour, then combined with water for later consumption. According to Cerqueira et al. (1979), the diet of the Tarahumara consists $90 \%$ of maize and beans, with $94 \%$ of the total daily protein from vegetable sources, with 6\% from animal sources. 
Previous studies on the parasitological survey on the coprolites from the same site (Jiménez et al. 2012; Morrow 2016; Morrow and Reinhard 2016; Morrow and Reinhard 2018) showed a diversity of parasites at the site. Species of parasites that occur in humans recovered from coprolites include the trematode Echinostoma sp., the nematodes Enterobius vermicularis and Trichuris trichiura, and the cestodes Hymenolepis sp. and Dipylidium caninum. The presence of these parasites, especially the nematodes, could cause some pathogenesis. The high concentration of $E$. vermicularis evidenced by the previous studies (Hugot et al. 1999; Jiménez et al. 2012;Morrow and Reinhard 2018) signals that the population could have a serious case of pinworm infection. Parasitic infection can produce health problems and can be associated with growth deficiencies and reduction in health status (Zonta et al. 2010). Although there was a diversification of food available, the nutrition intake could then be reduced due to the parasitic infection that occurred among the individuals.

A previous analysis of the gut microbiome by Tito et al. (2008, 2012) extracted DNA from two coprolites from the same site. The samples presented in this analysis were from the same contexts as those successfully analyzed by gut microbiome researchers (Hagan et al. 2019; Schnorr et al. 2016; Tett et al. 2019a, b; Tito et al. 2008, 2012). Since CMC revealed bacterial DNA in these separate studies, we are confident that the same population represented in our study was sampled for the gut microbiome studies. These came from other samples from the same grids; therefore, the results from these two studies can provide some insightful information on the general gut microbiome of the population that inhabited the cave. Signatures from the coprolites show similarities with the gut bacteria that occurs in children from a rural African village, also analyzed in the study by Tito et al. (2008, 2012). Bacteria from the genus Bifidobacterium, common in breastfed children and infants, and Treponema berlinense were found in these coprolite samples. In the burials, skeletons of children were found so the presence of these bacteria is expected.

The occurrence of $T$. berlinense in the gut microbiome of the coprolites might be explained by the diet of the population. Previous studies by Nordhoff et al. (2005) have shown that T. berlinense occurs in porcine feces. Yet other studies have shown that T. berlinense also occurs in the gut microbiome of people that inhabit traditional rural populations, such as the Amazonians from French Guiana (Angelakis et al. 
2019a). The study by Angelakis et al. (2019a) compared the gut microbiome between traditional rural and urban populations and has shown that Treponema was detected mostly on rural populations. The study by Angelakis et al. (2019a) proposes that the high-fiber diet has an impact on the microbiome explaining the higher occurrence of T. berlinense in rural populations, when compared with urban populations. The authors in another study (Angelakis et al. 2019b) also suggest that the close proximity of animals and humans can be a reason for the occurrence of this bacterium in these populations, as it was also found in wild apes, macaques, and hominids. Thus, the presence of $T$. berlinense in the microbiome of the Loma San Gabriel could be related to their diet intake; however, to fully understand the presence of this bacteria in the ancient human microbiome, further studies should be done. In this study, the diet analysis has shown the presence of a high quantity of fiber due to the presence of Agave hearts, which would corroborate with previous findings of $T$. berlinense.

A new analysis of CMC coprolites focused on the Prevotella copri complex (Tett et al. 2019a. b). These researchers assert that the $P$. copri complex is strongly linked with non-Westernized peoples who have high-fiber diets with complex carbohydrates. These diets are also low in fats and animal protein. They found the P. copri complex to be prevalent in the CMC ancient gut metagenome. This is consistent with the high-fiber diet with low meat we found. The authors write, "Diet in particular seems to play a pivotal role in the case of $P$. copri, yet there is lack of studies where dietary information is available or cohorts focused specifically on dietary regimes to adequately address this association. Clearly more work is required both in silico and in vitro studies to functionally associate and characterize the $P$. copri complex with respect to diet" (Tett et al. 2019a, b). Our work attempts to address this absence of study by direct dietary analysis of coprolites.

In this paper, we reconstruct meals from 10 different coprolites based on the microscopic and macroscopic remains, and correlate with previous studies from the same archeological site. More importantly, we also highlight how diet data could be used to interpret the human gut microbiome, for example, the presence of T.berlinense and the $P$. copri complex. We propose that researchers who study the microbiome from archeological samples also analyze the microscopic and macroscopic dietary remains, since food patterns shape and interfere on the hosts' microbiome impacting on the presence/ 
absence of species of bacteria that occur on the microbiome (Angelakis et al. 2019a). Studies on microbiome of archeological samples focus mostly on New Generation Sequencing (NGS) (Tito et al. 2008, 2012; Lugli et al. 2017; Warinner et al. 2015); however, adding the information of the main diet of ancient populations can also help understand the role of the microbiome and how diet influences the microbial community.

Inherent in the results of our work is the similarity of Zape diet to historic Tarahumara people, due to the commonality in the use of small mammals, fish, and reptiles as protein sources (Irigoyen-Rascón 2015). With regard to plant foods, milled maize, huitlacoche, beans, Physalis, and fermented maize are shared between Zape and Tarahumara. Therefore, at some future date, we suggest that the gut microbiome of Zape coprolites should be compared with indigenous people of the Sierra Madre.

Funding information This study was financed by Conselho Nacional de Desenvolvimento Científico e Tecnológico (CNPq - 206047/2017-7).

\section{References}

Angelakis E, Bachar D, Yasir M, Musso D, Djossou F, Gaborit B et al (2019a) Treponema species enrich the gut microbiota of traditional rural populations but are absent from urban individuals. New Microbes New Infections 27:14-21

Angelakis E, Bachar D, Yasir M, Musso D, Djossou F, Melenotte C et al (2019b) Comparison of the gut microbiota of obese individuals from different geographic origins. New Microbes and New Infections. https://doi. org/10.1016/j.nmni.2018.11.005

Arendt M, Cairns KM, Ballard JWO, Savolainen P, Axelsson E (2016) Diet adaptation in dog reflects spread of prehistoric agriculture. Heredity 117(5):301

Armelagos GJ (1994) You are what you eat. Paleonutrition: the diet and health of prehistoric Americans Southern Illinois University at Carbondale Center for Archaeological Investigations Occasional Paper 22:235-244

Backwell LR, D'Errico F (2001) Evidence of termite foraging by Swartkrans early hominids. Proc Natl Acad Sci 98:1358-1363

Brooks RH, Kaplan L, Cutler HC, Whitaker TW (1962) Plant material from a cave on the Rio Zape, Durango, Mexico. Am Antiq 27(3): 356-369

Butler JRA, Du Toit JT (2002) Diet of free-ranging domestic dogs (Canis familiaris) in rural Zimbabwe: implications for wild scavengers on the periphery of wildlife reserves. Animal Conservation Forum 5(1): 29-37 
Cano RJ, Rivera-Perez J, Toranzos GA, Santiago-Rodriguez TM, NarganesStorde YM, Chanlatte-Baik L et al (2014) Paleomicrobiology: revealing fecal microbiomes of ancient indigenous cultures. PLoS One 9(9):e106833

Cerqueira MT, Fry MM, Connor WE (1979) The food and nutrient intakes of the Tarahumara Indians of Mexico. Am J Clin Nutr 32(4): 905-915

Davenport ER, Sanders JG, Song SJ, Amato KR, Clark AG, Knight R (2017) The human microbiome in evolution. BMC Biology. https://doi.org/10.1186/ s12915-017-0454-7

David LA, Maurice CF, Carmody RN, Gootenberg DB, Button JE,Wolfe BE et al (2014) Diet rapidly and reproducibly alters the human gut microbiome. Nature 505(7484):559

Dean GW (2006) The science of coprolite analysis: the view from Hinds Cave. Palaeogeogr Palaeoclimatol Palaeoecol 237(1):67-79

Dominguez-Bello MG, Blaser MJ (2011) The human microbiota as a marker for migrations of individuals and populations. Annu Rev Anthropol 40:451-474

Gómez B, Junghans C, Aldasoro EM, Grehan JR (2016) The ghost moth (Lepidoptera: Hepialidae) as food of indigenous people in Mexico. J Insects Food Feed 2(1):53-59

Hagan RW, Hofman CA, Hübner A, Reinhard K, Schnorr S, Lewis CM Jr, Sankaranarayanan K, Warinner CG (2019) Comparison of extraction methods for recovering ancient microbial DNA from paleofeces. Am J Phys Anthropol. https://doi.org/10.1002/ajpa.23978

Hammerl EE, Baier MA, Reinhard KJ (2015) Agave chewing and dental wear: evidence from quids. PLoS One 10(7):e0133710

Hugot JP, Reinhard KJ, Gardner SL, Morand S (1999) Human enterobiasis in evolution: origin, specificity and transmission. Parasite 6: 201-208

Irigoyen-Rascón F (2015) Tarahumara medicine: ethnobotany and healing among the Rarámuri of Mexico. University of Oklahoma Press

Jiménez FA, Gardner SL, Araújo A, Fugassa M, Brooks RH, Racz E, Reinhard KJ (2012) Zoonotic and human parasites of inhabitants of Cueva de Los Muertos Chiquitos, Rio Zape Valley, Durango, Mexico. J Parasitol 98(2):304-310

Juárez-Montiel M, de León SR, Chávez-Camarillo G, Hernández- Rodríguez C, Villa-Tanaca L (2011) Huitlacoche (corn smut), caused by the phytopathogenic fungus Ustilago maydis, as a functional food. Rev Iberoam Micol 28(2):69-73

Kelso GK, SolomonAM(2006) Applying modern analogs to understand the pollen content of coprolites. Palaeogeogr Palaeoclimatol Palaeoecol 237(1):80-91

Linskens HF, Jorde W (1997) Pollen as food and medicine-a review. Econ Bot 51(1):78

Lugli GA, Milani C, Mancabelli L, Turroni F, Ferrario C, Duranti S et al (2017) Ancient bacteria of the Ötzi's microbiome: a genomic tale from the Copper Age. Microbiome 5:5

Meade T (1994) A dietary analysis of coprolites from a prehistoric Mexican cave site. Thesis, University of Nebraska-Lincoln. 
Monárrez-Espino J, Martínez H, Greiner T (2001) Iron deficiency anemia in Tarahumara women of reproductive-age in Northern Mexico. Salud Publica Mex 43:392-401

Morrow JJ (2016) Exploring parasitism in antiquity through the analysis of coprolites and quids from La Cueva de los Muertos Chiquitos, Rio Zape, Durango, Mexico. Dissertation, University of Nebraska - Lincoln.

Morrow JJ, Reinhard KJ (2016) Cryptosporidium parvum among coprolites from La Cueva de los Muertos Chiquitos (6oo-80o CE), Rio Zape Valley, Durango, Mexico. J Parasitol 102(4):429-435

Morrow JJ, Reinhard KJ (2018) The paleoepidemiology of Enterobius vermicularis (Nemata: Oxyuridae) Among the Loma San Gabriel at La Cueva de losMuertos Chiquitos (6oo-80o CE), Rio Zape Valley, Durango, Mexico. Comp Parasitol 85(1):27-33

Nordhoff M, Taras D, Macha M, Tedin K, Hans-Jurgen B, Wieler LH (2005) Treponema berlinense sp. nov., novel spirochaetes isolated from porcine feces. Int J Syst Evol Microbiol 55:1675-1680

Oeggl K, Kofler W, Schmidl A, Dickson JH, Egarter-Vigl E, Gaber O (2007) The reconstruction of the last itinerary of "Ötzi", the Neolithic Iceman, by pollen analyses from sequentially sampled gut extracts. Quat Sci Rev 26(7-8):853-861

Patel S (2016) Nutrition, safety, market status quo appraisal of emerging functional food corn smut (huitlacoche). Trends Food Sci Technol 57:93-102

Quiñónez-Martínez M, Ruan-Soto F, Aguilar-Moreno IE, Garza-Ocañas F, LebgueKeleng T, Lavín-Murcio PA, Enríquez-Anchondo ID (2014) Knowledge and use of edible mushrooms in two municipalities of the Sierra Tarahumara, Chihuahua, Mexico. J Ethnobiol Ethnomed 10:67

Ramos-Elorduy J (2009) Anthropo-entomophagy: cultures, evolution and sustainability. Entomol Res 39(5):271-288

Reinhard KJ (1993) The utility of pollen concentration in coprolite analysis: expanding upon Dean's comments. J Ethnobiol 9:31-44

Reinhard KJ, Hevly RH (1991) Dietary and parasitological analysis of coprolites recovered from mummy 5, Ventana Cave, Arizona. Kiva 56(3):319-325

Reinhard KJ, Edwards SK, Damon TR, Meier DK (2006) Pollen concentration analysis of ancestral Pueblo dietary variation. J Palaeogeogr Palaeoclimatol Palaeoecol 237:92-109

Reinhard KJ, Johnson KL, LeRoy-Toren S,Wieseman K, Teixeira-Santos I, Vieira M (2012) Understanding the pathoecological relationship between ancient diet and modern diabetes through coprolite analysis: a case example from Antelope Cave, Mojave County, Arizona. Curr Anthropol 53:506-512

Ruiz-Herrera J, Martínez-Espinoza AD (1998) The fungus Ustilago maydis, from the aztec cuisine to the research laboratory. Int Microbiol 1(2):149-158

Saboo SS, Thorat PK, Tapadiya GG, Khadabadi SS (2013) Ancient and recent medicinal uses of cucurbitaceae family. International Journal of Therapeutic Applications 9:11-19 
Schnorr SL, Sankaranarayanan K, Lewis CM Jr, Warinner C (2016) Insights into human evolution from ancient and contemporary microbiome studies. Curr Opin Genet Dev 41:14-26

Sobolik K (1994) Paleonutrition: the diet and health of prehistoric Americans. In: Southern Illinois University, Carbondale, Center for Archaeological Investigations Occasional Paper

Sponheimer M, Lee-Thorp J, de Ruiter D, Codron D, Codron J, Baugh AT, Thackeray F (2005) Hominins, sedges, and termites: new carbon isotope data from the Sterkfontein valley and Kruger National Park. J Hum Evol 48:301-312

Stockmarr J (1971) Tablets with spores used in absolute pollen analysis. Pollen et Spores 13(4):615-21

Tett A, Huang KD, Asnicar F, Fehlner-Peach H, Pasolli E, Karcher N, Armanini F, Manghi P, Bonham K, Zolfo M, De Filippis F (2019a) The Prevotella copri complex comprises four distinct clades that are underrepresented in Westernised populations. BioRxiv, p 600593

Tett A, Huang KD, Asnicar F et al (2019b) The Prevotella copri complex comprises four distinct clades that are underrepresented in Westernised populations. BioRxiv, p 600593

Tito RY, Macmil S, Wiley G, Najar F, Cleeland L, Qu C et al (2008) Phylotyping and functional analysis of two ancient human microbiomes. PLoS One 3(11):e3703

Tito RY, Knights D, Metcalf J, Obregon-Tito AJ, Cleeland L, Najar F et al (2012) Insights from characterizing extinct human gut microbiomes. PLoS One $7: \mathrm{e} 51146$

Van Huis A (2017) Did early humans consume insects? J Insects Food Feed 3(3):161-163

Vinton SD, Perry L, Reinhard KJ, Santoro CM, Teixeira-Santos I (2009) Impact of empire expansion on household diet: the Inka in Northern Chile's Atacama Desert. PLoS One 4(11):e8069

Warinner C, Speller C, Collins MJ (2015) A new era in palaeomicrobiology: prospects for ancient dental calculus as a long-term record of the human oral microbiome. Philos Trans R Soc B. https://doi.org/10.1098/rstb.2013.0376

Warnock PJ, Reinhard KJ (1992) Methods for extracting pollen and parasite eggs from Latrine Soils. J Archaeol Sci 19:261-264

Weyrich LS, Duchene S, Soubrier J, Arriola L, Llamas B, Breen J et al (2017) Neanderthal behaviour, diet, and disease inferred from ancient DNA in dental calculus. Nature 544(7650):357

Zonta ML, Oyhenart EE, Navone GT (2010) Nutritional status, body composition, and intestinal parasitism among the Mbyá-Guaraní communities of Misiones, Argentina. American Journal of Human Biology: The Official Journal of the Human Biology Association 22(2):193-200 